\title{
Biochemical \\ Characterization \\ of \\ Lipopolysaccharide of Ralstonia solanacearum and its Relation to Virulence
}

El-Meneisy, A.Z.A. ${ }^{1}$; Hamed, A.H. ${ }^{1}$; Abd El-Said, W.M. ${ }^{1}$; Soliman, Kh.A.A. ${ }^{2}$ and Abd El-Ghafar, N.Y. ${ }^{1}$

1- Plant Pathology Department, Faculty of Agriculture, Ain Shams University O. Box: 68, Hadayek Shobra 11241, Cairo, Egypt.

2- Genetics Dept, Fac. Agric., Ain Shams Univ., Shoubra ElKheima- Cairo, Egypt.

\begin{abstract}
This work was planned to study biochemical characters for $R$. solanacearum lipopolysaccharide (LPS) and its relation to virulence. All tuber isolates were highly virulence compared with soil and water isolates. These isolates were divided into two groups according to disease incidence and disease severity; the first group contained virulent isolates which isolated from tuber samples and the second group contained avirulent isolates which isolated from soil and water samples. Virulent isolates showed high content of either lipopolysaccharide or total sugars in LPS compared with avirulent isolates. Total sugars in LPS were determined using gas liquid chromatography (GLC). The glucose was the major content of $R$. solanacearum lipopolysaccharide in all examined isolates. Lipopolysaccharide for virulent isolates of $R$. solanacearum showed high amount of arabinose, xylose, mannose and galactose compared with the avirulent isolates, while the amount of mannitol was the highest in Lipopolysaccharide for avirulent isolates compared with virulent isolates. There is no significant difference for the amount of rhamnose, fructose and sorbitol in lipopolysaccharide for all isolates.
\end{abstract}

Keywords: Potato, Solanum tuberosum, bacterial wilt, Ralstonia solanacearum, Virulent, Avirulent isolates, monosaccharide, Lipopolysaccharide.

Ralstonia solanacearum (formerly Burkholderia or Pseudomonas solanacearum) Yabuuchi et al., (1995) is the causative agent of bacterial wilt, which affects numerous host plants of economic importance worldwide (Kelman, 1953; Buddenhagen and Kelman, 1964 and Hayward, 1964). The bacterium is found worldwide, mainly in tropical and subtropical areas, but also in warm-temperate countries and even in some cool-temperate regions (Hayward et al, 1998). Strains of $R$. solanacearum are differentiated into five races according to host range and six biovars according to the ability to oxidize three disaccharides and three hexose alcohols (Buddenhagen and Kelman, 1964; Hayward, 1964 and Williamson et al., 2002).

The lipopolysaccharide (LPS) protects the bacterial cell from hostile environments and in pathogenic bacteria, they represent important virulence factors through their direct interaction with eukaryotic host cells. Mutants of phytopathogenic bacterial strains with defects in their LPS biosynthesis, frequently 
show reduced virulence and the number of viable bacteria in plant tissues declines rapidly (Esposito et al., 2008). LPS are ubiquitous, indispensable components of the cell surface of gram-negative bacteria and their taxonomy that apparently have diverse roles in bacterial pathogensis of plant (Erbs and Newman, 2003 and Varbanets et al., 2004). Abundant Exopolysaccharide (EPS) produced by pathogenic strains of Ralstonia solanacearum on solid medium and in planta has long been correlated with its pathogenicity (Araud-Razou et al., 1998 and Esposito et al., 2008).

The aim of this work was to study the biochemical characters of the lipopolysaccharide (LPS) produced by $R$. solanacearum isolates in relation to its virulence.

\section{Materials and Methods}

\section{Bacterial isolates:}

Ten isolates of $R$. solanacearum (TD14, TG6, TK8, TM7, TK16, SG1, SK3, SM4, WK2 and WM3) were isolated from different samples (potato tubers, soil, and water) collected from Dakahlia, Gharbiya, Kalubiya and Menoufiya governorates. One isolate (Rs) was obtained from potato brown rot project, Dokki, Giza, Egypt and used as a reference isolate. These isolates were identified using traditional and standard tests according to Dhital et al., 2001.

Plant growth and pathogen inoculation:

Healthy potato tubers (Nicola, cv.) were obtained from Potato Brown Rot Project, Dokki, Giza, Egypt. It was stored at $4^{\circ} \mathrm{C}$ for 20 days and placed at room temperature to stimulate germination. Germinated tubers were planted in clay pots $(25 \mathrm{~cm}$, diameter) containing sterilized soil-sand mixture (1:1, v:v) under greenhouse conditions. Plants were allowed to grow to a height of $20-25 \mathrm{~cm}$ and inoculated with Ralstonia solanacearum isolates, using soil drench method.

The bacterial isolates were streaked on triphenyl tetrazolium chloride agar medium (TTC) and incubated at $28^{\circ} \mathrm{C}$ for $48 \mathrm{~h}$. Bacterial cells were suspended with sterile distilled water (SDW) and adjusted to $\mathrm{A} 600=0.1$ (about $10^{8}$ cells $/ \mathrm{ml}$ ). Bacterial suspension was poured around the base of each plant, and an alcoholflamed knife was inserted 4-5 cm into the soil to cut the root along one side (Kempe and Sequeira, 1983 and Adhikari, 1993).

Disease assessment:

Disease incidence (DI) was recorded after 60 days from inoculation with $R$. solanacearum isolates. The disease was estimated as percentage of wilted shoots (No. of wilted shoots/total number of shoots $\times 100$ ) and disease severity according to $0-4$ rating scale, where $0=$ no symptoms, $1=$ up to $25 \%$ of the foliage wilted, $2=$ $25-50 \%$ of the foliage wilted, $3=50-75 \%$ of the foliage wilted and $4=75-100 \%$ of the foliage wilted (Kempe and Sequeira, 1983). Percentage of disease severity (DS) was calculated as following:

$$
\mathrm{DS}=(\Sigma \mathrm{R} . \mathrm{T} / \mathrm{N} \times \mathbf{4}) \times \mathbf{1 0 0}
$$

$\mathrm{T}=$ Number of plants per degree rating (R 0-4)

$\mathrm{N}=$ Total number of tested plants

Egypt. J. Phytopathol., Vol. 39, No. 1 (2011) 
Also, mean disease rating was calculated and used to determine virulence of isolates.

Extraction of R. solanacearum lipopolysaccharide (LPS):

Isolates of $R$. solanacearum were grown at $28^{\circ} \mathrm{C}$ under shaking $(240 \mathrm{rpm})$ in 500 $\mathrm{ml}$ flasks filled with $200 \mathrm{ml}$ of a synthetic medium contained, in grams per liter: $\left(\mathrm{MgSO}_{4} .7 \mathrm{H} 20,0.2 ; \mathrm{KH}_{2} \mathrm{PO}_{4}, 3.0 ; \mathrm{Na}_{2} \mathrm{HPO}_{4}, 6.0\right.$, and glucose, 5.0). Approximately $0.1 \mathrm{ml}$ of bacterial suspension $\left(10^{8} \mathrm{cfu} / \mathrm{ml}\right)$ was inoculated into the liquid medium and incubated for $48 \mathrm{~h}$ at $28^{\circ} \mathrm{C}$. Cells were centrifuged at $8000 \mathrm{~g}$ at $4{ }^{\circ} \mathrm{C}$ for $30 \mathrm{~min}$. The wet cells were suspended with acetone and diethyl ether (Varbanets et al., 2004), and weighed sample of cell was extracted three times at $68^{\circ} \mathrm{C}$ with a $45 \%$ solution of phenol. After each extraction, the sample was cooled to $10{ }^{\circ} \mathrm{C}$ and centrifuged at $1,000 \mathrm{~g}$ for $45 \mathrm{~min}$. The water phases from the three extractions were combined and washed three times with ether to remove phenol. Crude LPS was sedimented by ultracentrifugation (Beckman ModelL.2) at 100,000 $\mathrm{g}$ for $3 \mathrm{~h}$ at $4^{\circ} \mathrm{C}$ (Westphal and Jann, 1965).

Phenol sulfuric method was used to determine total sugars in LPS. A known weight of lipopolysaccharide was dissolved in one $\mathrm{ml}$ of $0.05 \mathrm{~N} \mathrm{HCl}$ in a screw capped test tube. The tube was then heated in a water bath at $70^{\circ} \mathrm{C}$ for $30 \mathrm{~min}$. Total sugars in this LPS solution was determined as described by Dubois et al. (1956) as follows: $0.5 \mathrm{ml}$ of the LPS solution was added in a clean test tube followed by 0.5 $\mathrm{ml}$ of $5 \%$ phenol and shaked well. Concentrated sulfuric acid $(2.5 \mathrm{ml})$ was slowly added at the wall of the test tube. The tubes shaked well and allowed to cool. The absorbance was measured at 490nm against a blank tube. Standard curve was made from glucose in a concentration range from $20 \mu \mathrm{g}$ to $80 \mu \mathrm{g} / \mathrm{ml}$.

Analysis of $R$. solanacearum lipopolysaccharide (LPS):

A known weight of the lipopolysaccharide (about $10 \mathrm{mg}$ ) was added in a screwcapped test tube. Two $\mathrm{ml}$ of $1 \mathrm{~N} \mathrm{HCl}$ were added, and the solution was hydrolyzed at $100^{\circ} \mathrm{C}$ for $6 \mathrm{~h}$ in an oven. The solution was evaporated to dryness at $40^{\circ} \mathrm{C}$ under stream of nitrogen. After that, $0.5 \mathrm{ml}$ of isopropanol (HPLC grade) was added to remove any residue of water, shaked gently, and evaporated to dryness under a stream of nitrogen at $40^{\circ} \mathrm{C}$. Approximately $250 \mu$ of oximation solution $(2.5 \%$ of hydroxylamine hydrochloride in anhydrous pyridine) was added and put in an oven at $80^{\circ} \mathrm{C}$ for $30 \mathrm{~min}$. After cooling, $0.5 \mathrm{ml}$ of sialylation reagent (trimethylchlorosilane: N,N-O bis-(trimethylsilyl) acetamide, 1:5 v:v) was added and put in an oven at $8^{\circ} \mathrm{C}$ for $30 \mathrm{~min}$ (Kirk and Sawyer 1991). Two $\mu \mathrm{l}$ of this final product was injected in gas liquid chromatography (GLC) instrument (HewlettPackard 6890) on a capillary column of HP-l stationary phase. The absolute configurations of the monosaccharides were determined by GLC of the acetylate glycoside with (-)-2-octahol.

Egypt. J. Phytopathol., Vol. 39, No. 1 (2011) 


\section{Results and Discussion}

Determination of virulence of Ralstonia solanacearum isolates:

Ten isolates of $R$. solanacearum were examined to determine their virulence on potato plants, using soil drench method. These isolates were obtained from tuber (TD14, TG6, TK8, TM7 and TK16), soil (SG1, SK3 and SM4) and water (WK2 and WM3) samples. The results shown in Fig. (1) indicate that all tuber isolates were highly virulent compared with soil and water isolates. Isolates from the soil and irrigation water didn't cause apparent infection and/or symptoms on potato plants. Therefore, these isolates were divided into two groups according to disease incidence. The first group contained virulent isolates (TD14, TG6, TK8, TM7 and TK16) which isolated from tuber samples where the disease incidence ranged from $71.9-75.6 \%$ with disease severity of $62.7-66.8 \%$. The second group contained avirulent isolates (SG1, SK3, SM4, WK2 and WM3) which were isolated from soil and water samples, where no disease incidence was recorded.

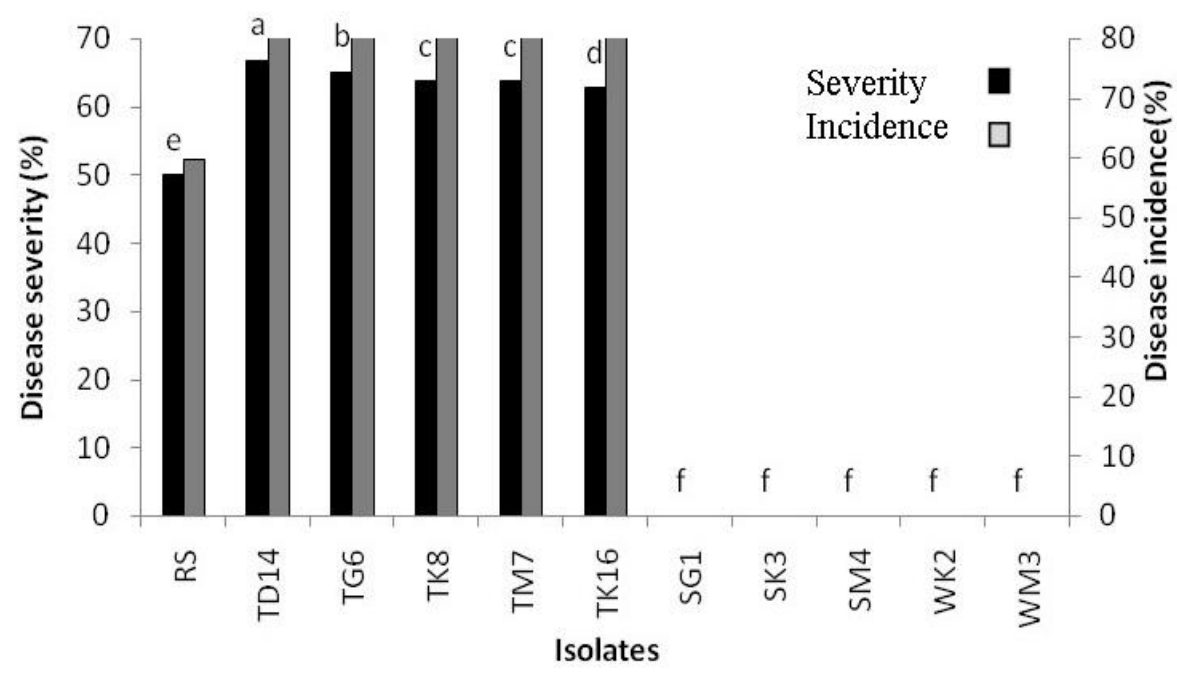

Fig (1): Determination of virulent and avirulent isolates of $R$. solanacearum according to disease incidence and severity, using soil drench method, under artificial inoculation conditions.

Biochemical analysis of $R$. solanacearum lipopolysaccharide (LPS):

Data in Fig. (2) indicate that all the virulent isolates could produce high amount of lipopolysaccharide compared with the avirulent ones. Percentage of LPS ranged from 6.64 to $9.64 \%$ for the virulent isolates and 0.61 to $2.71 \%$ for the avirulent isolates. TD14, TK16 and TM7 Isolates from tubers showed the highest content of LPS, where percentage of LPS was $9.64,8.70$ and $8.28 \%$ respectively. Meantime, WM3, SM4 and SG1 isolates from water and soil showed the lowest content of LPS, where percentage of LPS was $0.61,1.52$ and $1.85 \%$ respectively.

Egypt. J. Phytopathol., Vol. 39, No. 1 (2011) 


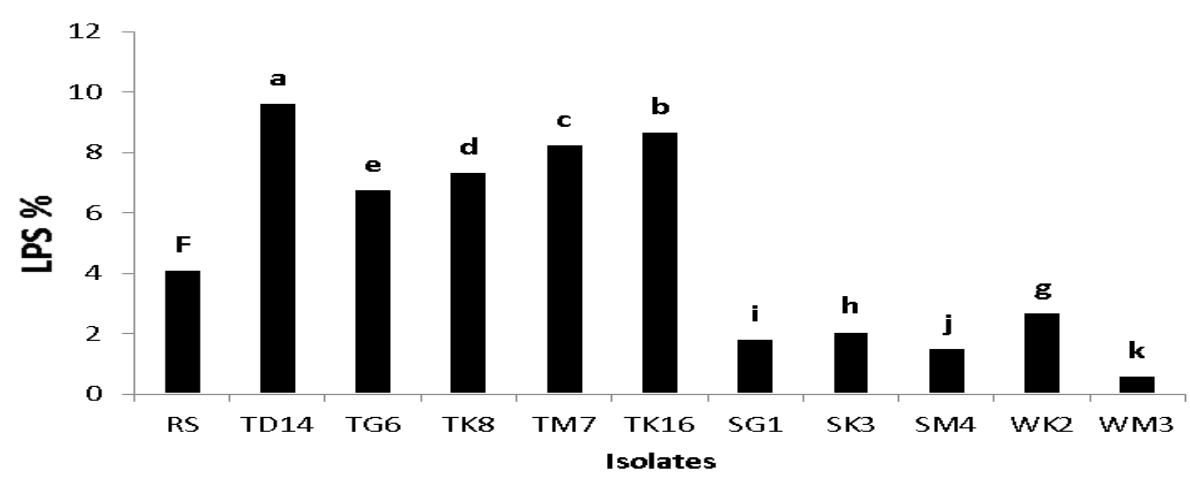

Fig. (2): Percentage of lipopolysaccharide (LPS) in isolates of Ralstonia solanacearum obtained from different sources (tuber, soil, irrigation water) (Columns followed by the different letter are significantly different at $\mathbf{P}=\mathbf{0 . 0 5}$ according to Duncan's multiple range test) and 0.0 $1.88 \%$, respectively.

Virulent isolates (TD14, TG6, TK8, TM7 and TK16) appeared high content of sugar compared with avirulent isolates (SG1, SK3, SM4, WK2 and WM3), where percentage of sugar was $6.41-13.03 \%$ of LPS for virulent isolates and $1.3-3.3 \%$ of LPS for avirulent isolates. Isolate of TK16 had the highest content of sugar, where percentage of sugar was $13.02 \%$ of LPS, but isolates of TD14, TG6, TM7 and TK8 had average amount of sugar, where percentage of sugar was 7.84, 7.18, 6.67 and $6.41 \%$ of LPS, respectively. Meanwhile, isolates of SK3, SM4, WK2, WM3 and SG1 had the least content of LPS, where percentage of sugar was 1.36,2.48,2.93,3.11 and 3.30\% of LPS, respectively (Fig.3).

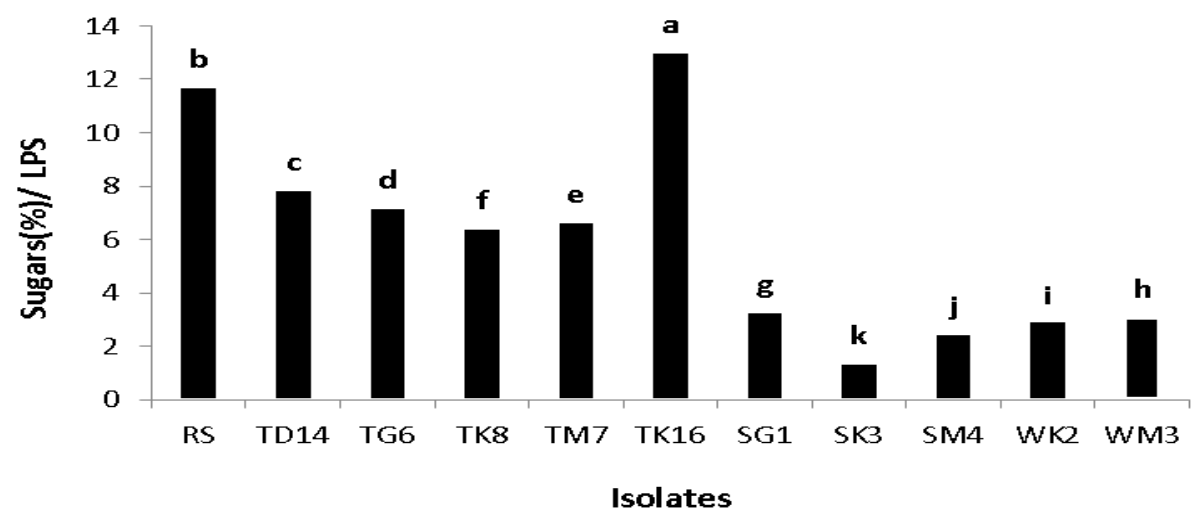

Fig. (3): Percentage of sugar content in lipopolysaccharide (LPS) for different virulent and avirulent isolates of Ralstonia solanacearum (Columns followed by the different letter are significantly different at $P=0.05$ according to Duncan's multiple range test). 
Data shown in Table (1) prove that glucose was the major content of $R$. solanacearum lipopolysaccharide, where its percentage was 66.3-90.85\%. However, percentage of arabinose, rhamnose, mannose and galactose were 1.03-7.89, 2.27-

$5.33,1.03-8.62$ and 1.00-9.09 \% of lipopolysaccharide, respectively. Meanwhile, xylose, sorbitol and fructose were less frequent in $R$. solanacearum lipopolysaccharide, where their percentages were $0.0-3.05,0.0-1.39,0.0-3.31$. (Columns followed by the different letter are significantly different at $\mathrm{P}=0.05$ according to Duncan's multiple range test).

However, arabinose, xylose, rhamnose, mannose and galactose were the major components in lipopolysaccharide of virulent isolates (TD14, TG6, TK8, TM7 and TK16). On the other hand, mannitol was an exclusive component in lipopolysaccharide of the avirulent isolates than the virulent ones (Table,1).

Table (1): Sugar analysis in lipopolysaccharides for Ralstonia solanacearum isolates, using Gas chromatography.

\begin{tabular}{|c|c|c|c|c|c|c|c|c|c|}
\hline \multirow[b]{2}{*}{ Isolate } & \multicolumn{9}{|c|}{ Sugars } \\
\hline & 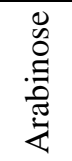 & $\frac{\infty}{\infty}$ & 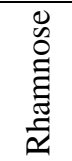 & $\begin{array}{l}\overrightarrow{0} \\
\stackrel{0}{0} \\
\stackrel{0}{0} \\
\mathscr{n}\end{array}$ & $\begin{array}{l}\overline{\stackrel{0}{\Xi}} \\
\text { 芯 }\end{array}$ & 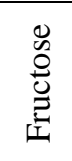 & $\begin{array}{l}\mathscr{\infty} \\
\stackrel{\Xi}{\Xi} \\
\stackrel{\Xi}{\Sigma}\end{array}$ & 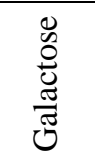 & $\begin{array}{l}0 \\
\infty \\
0 \\
0 \\
0 \\
0\end{array}$ \\
\hline $\mathrm{RS}$ & 4.66 & 3.65 & 3.65 & 4.56 & 0.00 & 0.00 & 12.16 & 12.66 & 58.66 \\
\hline TD14 & 7.89 & 2.72 & 5.33 & 1.39 & 0.00 & 1.66 & 3.23 & 2.87 & 74.92 \\
\hline TG6 & 6.58 & 2.51 & 5.02 & 0.00 & 0.00 & 1.88 & 8.62 & 9.09 & 66.30 \\
\hline TM7 & 3.43 & 3.05 & 3.86 & 0.00 & 0.91 & 0.64 & 5.73 & 2.78 & 79.60 \\
\hline TK16 & 4.38 & 2.38 & 4.29 & 0.00 & 0.87 & 0.38 & 2.43 & 2.29 & 82.98 \\
\hline SG1 & 1.30 & 0.70 & 2.87 & 0.00 & 1.48 & 1.04 & 4.70 & 1.39 & 86.52 \\
\hline SK3 & 2.37 & 0.00 & 2.93 & 0.34 & 2.44 & 0.00 & 2.34 & 1.95 & 87.63 \\
\hline SM4 & 1.03 & 0.00 & 2.27 & 0.00 & 3.31 & 0.27 & 1.03 & 1.24 & 90.85 \\
\hline WK2 & 2.53 & 0.00 & 3.32 & 0.00 & 3.00 & 0.26 & 3.83 & 1.95 & 85.12 \\
\hline WM3 & 1.29 & 0.00 & 4.58 & 0.00 & 3.17 & 0.00 & 3.60 & 1.00 & 86.35 \\
\hline
\end{tabular}

It is well known that $R$. solanacearum produces a variety of extracellular products that contribute to its ability to colonize host plants and cause disease symptoms. One of the most important of these is an acidic, high molecular mass extracellular polysaccharide (EPS1) (Genin and Bocher, 2002). Denny and Baek (1991) and Kao et al. (1992) suggested that EPS1 is the cause of wilting in infected plants, as it blocks the vascular system and thereby alters water movement. Although none of these EPS1-eficient mutants was totally non-pathogenic due to that these mutants poorly colonize the stem of infected plants suggest that EPS1 may contribute to minimizing or avoiding the recognition of bacterial surface structures by plant defense mechanisms (Aroud-Razou et al., 1998 and Saile et al., 1997).

Our results agree with several authors who indicated that mutant of $R$. solanacearum, with defects in their LPS biosynthesis, frequently show reduced virulence (Esposito et al., 2008). It is known from early reports that an absolute

Egypt. J. Phytopathol., Vol. 39, No. 1 (2011) 
correlation between EPS production and virulence in $R$. solanacearum is questionable. The results of the present study demonstrate that variation in most external polysaccharides is correlated with pathogen virulence.

In rich medium the wild type of $R$. solanacearum produces three EPSs (Orgambide et al.,1991 and Trigalet-Demery et al., 1993). The high-molecularweight acidic polymer EPS1, which account for up to $90 \%$ of the dry weight of the EPSs and two minor polymers, namely a N-acetyl-glucosaminorhamnan (EPS3) and a glucan (EPS4). The structure of the trisaccharidic repeating unit of EPS1, composed of $\mathrm{N}$-acetyl-galactoseamine, $\mathrm{N}$-acetyl-galactoseaminuronic acid and

bacillosamine derivative in an equimolar ratio has been established (Orgambide et al.,1991). The EPS produced in planta by $R$. solanacearum increases the viscosity of the sap and may thus block the vascular stream within xylem vessels (Husain and Kelman, 1958). Microscopic studies confirmed the accumulation of large amounts of bacterial EPS within infected vessels (Wallis and Truter, 1978 and Aroud-Razou et al., 1998) and demonstrated that spontaneous EPS-deficient mutant strain of $R$. solanacearum was unable to invade pro-toxylem vessels (Vasse et al.,1995).

\section{References}

Adhikari, T.B. 1993. Identification of biovars and races of Pseudomonas solanacearum and sources of resistance in tomato in Nepal. Plant Dis., 77: 905907.

Aroud-Razou, I.; Vasse, J.; Montrozier, H.; Etchebar, C. and Trigalet, A. 1998. Detection and visualization of the major acidic exopolysaccharide of Ralstonia solanacearum and its role in tomato root infection and vascular colonization. Eur. J. Plant Pathol., 104: 795-809.

Buddenhagen, I. and Kelman, A. 1964. Biological control and physiological aspects of bacterial wilt caused by Pseudomonas solanacearum. Annul Rev. Phytopathol., 2: 203-230.

Denny, T.P. and. Baek, S.R. 1991. Genetic evidence that extracellular polysaccharide is a virulence factor of Pseudomonas solanacearum. Mol. PlantMicrobe Interact., 4: 198-206.

Dhital, S.P.; Thaveechai, N. and. Shrestha, S.K 2001. Characteristics of Ralstonia solanacearum strains of potato wilt disease from Nepal and Thailand. Nepal Agric. Res. J., 5: 42-47.

Dubois, M.; Gilles, K.A.; Hamilton, J.K.; Repers, P.A and Smith, F. 1956. Colorimetric method for determination of sugars and related substance. Analytical Chem., 18: 350-356.

Erbs, G. and Newman, A.M. 2003. The role of lipopolysaccharide in induction of plant defence responses. Mol. Plant Pathol., 4: 421-425.

Esposito, N.; Ovchinnikova, G.; Barone, A.; Zoina, A.; Holst, O. and Evident, A. 2008. Host and non-host plant response to bacterial wilt in potato: Role of the

Egypt. J. Phytopathol., Vol. 39, No. 1 (2011) 
lipopolysaccharide isolated from Ralstonia solanacearum and molecular analysis of plant-pathogen interaction. Chem. and Biodivers., 5: 2662-2675.

Genin, S. and Boucher, C. 2002. Ralstonia solanacearum: secret of a major pathogen unveiled by analysis of its genome. Mol. Plant Pathol., 3: 111-118.

Hayward, A.C. 1964. Systematic and phylogeny of Pseudomonas solanacearum and related bacteria. In: Hayward, A.C. and G.L. Hartman (Eds) Bacterial wilt: The Disease and its Causative Agent, Pseudomonas solanacearum. (pp. 123-135)., Kluwer Academic publisher, Dordrecht, the Netherlands.

Hayward, A.C.; Elphistone, J.G.; Caffier, D.; Jense, J.; Stefani, E.; French, E.R. and Wrght, A.J. 1998. Bacterial wilt disease, Molecular and Ecological Aspects (Prior, P.; C., Allen and J., Elphinston, Eds) Springer-Verlag, Berlin, Germany. p.420.

Husain, A. and Kelman, A. 1958. Relation of slime production to mechanism of wilting and pathogenicity of Pseudomonas solanacearum. Phytopathology 48: 155-165.

Kao, C.C.; Barlow, E. and Sequeira, L. 1992. Extracellular polysaccharide is required for wild-type virulence of Pseudomonas solanacearum. J. Bacteriol., 174: 1068-1071.

Kelman, A. 1953. The bacterial wilt caused by Pseudomonas solanacearum. North Carolina Agricultural Experiment Station Technical Bulletin no., 99: 112-123.

Kempe, J. and L. Sequeira 1983. Biological control of bacterial wilt of potatoes: Attempts to induce resistance by treating tuber with bacteria. Plant Dis., 67: 499503.

Kirk, R.S and R. Sawyer 1991. Composition and Analysis of Foods. Pp 182-235. Longman Scientific Technical. New York.

Orgambide, G.; Montrozier, H.; Servin, P.; Roussel, J.; Trigalet-Demery, D. and Trigalet, A. 1991. High heterogeneity of the exopolysaccharides of Pseudomonas solanacearum strain GMI1000 and the complete structure of the major polysaccharide. J. Biol. Chem., 266: 8312-8321.

Saile, E.; McGarrey, J.A.; Schell, M.A. and Denny, T.P. 1997. Role of extracellular polysaccharide and endoglucanase in root invasion and colonization of tomato plants by Ralstonia solanacearum. Phytopathology, 87: 1264-1271.

Trigalet-Demery, D.; Montrozier, H.; Orgambide, G.; Patry, V.; Adam, O.; Navarro, L.; Cotelle, V. and Trigalet, A. 1993. Exopolysaccharides of Pseudomonas solanacearum: relation to virulence. In: Hartman, G.L. and A.C. Hayward (Eds) bacterial wilt. ACIAR Proceedings No. 45, Proceeding of an international symposium held in Kaohsiung, Taiwan pp. 312-315 Watson Ferguson and Company, Brisbane, Australia. 
Varbanets, L. D.; Brovarskaya, O.S.; Vasiliev, V.N.; Vinarskaya, N.V., and Gogoman, I.V. 2004. Characterization of lipids A of Ralstonia solanacearum lipopolysaccharides. ISSNO, 5: $233-7657$.

Vasse, J.; Frey, P. and Trigalet, A. 1995. Microscopic studies of intercellular infection and protoxylem invasion of tomato roots by Pseudomonas solanacearum. Mol. Plant-Microbe Interact., 8: 241-251.

Wallis, F. and Truter, S.J. 1978. Histopathology of tomato plants infected with Pseudomonas solanacearum with emphasis on ultrastructure. Physiol. Plant Pathol., 13: 307-317.

Westphal, O. and Jann, K. 1965. Extraction with phenol-water and further applications of the procedure. In Whistler, R.L. and M.L. Wolfrom (Eds.), Methods in Carbohydrate Chemistry, 5: 83. Pp. 83-91.

Williamson, L.; Nakaho, K.; Hudelson, B.; and Allen, C. 2002. Ralstonia solanacearum race 3 , biovar 2 strains isolated from geranium are pathogenic on potato. Plant Dis., 86: 987- 991.

Yabuuchi, E.; Kosako, Y.; Yano, I.; Hotta, H. and Nishiuchi, Y. 1995. Transfer of two Burkholderia and an Alcaligenes species to Ralstonia gen. nov.: proposal of Ralstonia picketii (Ralston, Palleroni and Doudoroff 1973) comb. Nov., Ralstonia solanacearum (Smith 1896) comb. nov. and Ralstonia eutropha (Davis 1969) comb. Nov. Microbiol. Immunol., 39: 897 - 904.

Corresponding author: El-Meneisy, A.Z.A.

E-mail: afaf_abdelaziz@agr.asu.edu.eg 


\author{
التوصيف البيوكيماوى لـ Lipopolysaccharide في الـ خلايا \\ بكتيريا Ralstonia solanacearum و علاقته بالثدة الإمر اضية

